\title{
DIPANGGIL KEPADA KEKUDUSAN
}

\author{
Agustinus Supriyadi \\ STKIP Widya Yuwana \\ atsywhw@yahoo.com
}

\begin{abstract}
Humans be created in the image of God. All people are called to holiness, that is to perfection, just as the Father in heaven is perfect. The theme called to holiness is first placed in the frame of the Basic Diocese of Surabaya which deals with the great theme of the Disciples of Christ. The theme of holiness contains elements about: what, when, where, who, why and how. The Kipling method or the $5 \mathrm{~W}-1 \mathrm{H}$ method helps the writer in describing this holiness theme. Being called to holiness in context has the same meaning as being called to be holy. Holiness itself has a charge as perfect love. Holiness and love are two inseparable things, because God is both Holy and Love. Human union with God is the essence of holiness. Holiness has a relationship with the perfection of love, so holiness cannot be understood separately from one's attitude and actions towards God through his actions towards the poor who suffer. Holiness is a lifestyle that is connected with daily life according to the Beatitues that Jesus conveyed to His disciples
\end{abstract}

Keywords: Called, Holiness (to be Holy)

\section{PENDAHULUAN}

Tema tentang dipanggil kepada kekudusan pertama-tama ditempatkan dalam bingkai Arah Dasar Keuskupan Surabaya yang terikat dengan tema yang lebih besar yaitu Murid-murid Kristus (Kemuridan). Pijakan dasarnya adalah pengakuan terhadap Yesus sebagai Guru yang harus menjadi panutan dan tuntunan dalam kehidupan kemuridan. Berangkat dari pengakuan tersebut, seorang dengan sadar dipanggil ke dalam kemuridan dan menuju kepada kesempurnaan hidup. Melalui Sakramen Baptis, para murid Kristus telah diselamatkan dan dikuduskan. Mereka dibebaskan dari dosa dan diangkat menjadi anak-anak Allah. Sebagai Murid Kristus, setiap warga Gereja telah menerima kabar sukacita. Kabar sukacita ini yang perlu diwartakan kepada orang lain. Sebab, murid Kristus dipanggil bukan untuk dirinya sendiri melainkan menjadi pewarta dan saksi Injil untuk semua orang, tugas ini diteguhkan dengan Sakramen Krisma. Dalam menjalankan tugas tersebut, perlu kekuatan yang digali dari 
sumber hidup yang sejati. Hal ini diharapkan arah murid Kristus senantiasa memiliki kekuatan ilahi dari Kristus sendiri, Sang Guru Sejati. Kekuatan itu digali dan diperoleh berkat Ekaristi. Ketiga Sakramen itu meletakkan dasar untuk panggilan bersama semua murid Kristus, untuk mencapai kekudusan dan membawa kabar gembira pada dunia.

Berbicara tentang panggilan kepada kekudusan, mengajak orang untuk berandai-andai dan membangun cita-cita yang acap kali tidak mudah untuk digapainya. Panggilan untuk menjadi kudus bukanlah suatu pilihan hanya untuk beberapa orang saja, melainkan menjadi kewajiban setiap orang Kristen. Kekudusan itu semata-mata diperoleh hanya karena rahmat Allah (1 Tes 4:3). Untuk mencapai kekudusan, setiap orang dituntut memiliki relasi pribadi yang mendalam dengan Yesus. Tanpa relasi itu, kekudusan hanya merupakan impian atau angan-angan belaka.

Topik tentang kekudusan mengandung muatan yang sangat padat dan berisi. Jika harus dianalisa, topik ini memiliki berbagai unsur yang sangat luas dan mendalam, antara lain: apakah hidup kudus itu identik dengan hidup yang jauh dari orang-orang berdosa? Seperti apa sebenarnya hidup kudus itu? Dan bagaimana panggilan kepada kekudusan itu harus dimaknai? Bagaimana tema tentang kekudusan ini memberi kontribusi bagi penghayatan murid-murid Kristus yang telah masuk dalam misteri inisiasi Kristiani? Dan masih banyak lagi muatan lain yang tersimpan dalam topik tersebut. Dalam rangka menguraikan tema tersebut, penulis dibantu oleh metode $5 \mathrm{~W}-1 \mathrm{H}$, atau yang sering dikenal dengan Metode Kipling (The Kipling Method).

The Kipling Method atau The 5W-1H method pada dasarnya adalah suatu metode yang digunakan untuk melakukan investigasi dan penelitian terhadap masalah yang terjadi dalam proses dan relasi sosial. 5W-1H merupakan singkatan dari 5W yaitu What, Whay, When- Where, Who dan $1 \mathrm{H}$ yaitu How. Jika diterjemahkan ke dalam bahasa Indonesia adalah : apa, di mana, kapan, mengapa, siapa dan bagaimana. Metode 5W-1H (Lima "W" Satu "H”) disebut dengan Metode Kipling (The Kipling Method) karena istilah 5W-1H ini pada awalnya diambil dari Puisi Rudyard Kipling pada tahun 1902 yang isinya adalah sebagai berikut: I have six faithful serving men. They taught me all I knew. Their names are What and Where and When. And Why and How and Who. Artinya: Saya memiliki enam pria yang setia melayani. Mereka mengajari saya semua yang saya tahu. Nama mereka adalah Apa dan Di Mana dan Kapan. Dan Mengapa dan Bagaimana dan Siapa (Kho, 2017 dan Kulsum, 2017:4). Dengan bantuan metode kipling atau The Kipling Method ini, secara sederhana, penulis menjabarkan tema tersebut di atas, meskipun tidak urut dan juga tidak luas serta mendalam. Dalam memberikan uraian tentang kekudusan ini, penulis lebih banyak mendasarkan diri pada pemikiran Konsili Vatikan II yang tertuang dalam 
Lumen Gentium (selanjutnya disingkat LG) 39-42 dan Seruan Apostolik Paus Fransiskus, yang tertuang dalam dokumen Gaudete et Exultate (selanjutnya disingkat GE). Penulis juga dibantu oleh nas-nas Alkitab serta beberapa tulisan lain yang membahas tentang tema kekudusan tersebut yang diharapkan memperteguh Arah Dasar Keuskupan Surabaya tentang Kemuridan.

\section{PEMBAHASAN}

2.1 Mengenal Dokumen Lumen Gentium, Gaudete et Exultate dan Kerangka Dasar Teologis Musyarawarah Pastoral Keuskupan Surabaya 2019

Pada tanggal 25 Januari 1959, di Basilika Santo Paulus Roma, Paus Yohanes XXIII mengejutkan umat Katolik semesta dengan isi maklumatnya untuk mengadakan Konsili Ekumenis ke-21 di Vatikan-Roma. Konsili ini dinamakan Konsili Vatikan II. Melalui konsili ini, Paus ingin memperbaharui Gereja Katolik Roma agar sesuai dan mampu menjawab tuntutan zaman serta menanamkan dan menumbuhkan semangat kesatuan di kalangan umat Kristen. Selain itu, Paus mengajak Gereja semesta berefleksi dan mengevaluasi diri berkenaan dengan proses pengembangan karya misinya di dunia (Hardawiryono, 2017: xi-xii). Keistimewaan konsili ini adalah: pertama, membaharui kehidupan rohani dalam terang Injil. Kedua, menyelaraskan Warta Injil dengan konteks kehidupan manusia, terutama dengan pelbagai tantangan dan tuntutan zaman modern. Ketiga, memulihkan persekutuan penuh di antara semua kaum Kristiani.

Khususnya pada bab kelima dalam Lumen Gentium, para Bapa Konsili menegaskan inti panggilan Umat Allah menuju kesucian. Dalam bab tersebut dipaparkan bahwa panggilan menuju kesucian dapat dilaksanakan dengan aneka cara dan diimani sebagai jalan menuju persatuan dengan Allah Trinitas. Tahun 2018, Paus Fransiskus menuliskan Seruan Apostolik Gaudete et Exultate, yang diterjemahkan dengan "Bersukacitalah dan Bergembiralah". Gaudete et Exsultate ini diberikan oleh Paus kelahiran Argentina (dengan nama Jorge Mario Bergoglio) di Saint Peter - Roma, pada Senin, 19 Maret 2018, bertepatan dengan peringatan Hari Raya Santo Yusuf, yaitu pada masa kepausannya yang keenam, semenjak ia terpilih sebagai Paus Gereja Katolik pada 13 Maret 2013. Mencermati isinya, seruan ini dapat dikatakan sebagai kelanjutan dari dokumen Lumen Gentium ayat 39-42. Harus diakui bahwa melalui Seruan Apostolik Gaudete et Exultate ini, Paus Fransiskus tidak bermaksud untuk menguraikan "kekudusan" secara rinci dan ilmiah (GE 2), melainkan lebih pada menggemakan kembali tentang panggilan kepada kekudusan, dengan mencoba mewujudkannya dalam konteks masa kini, dengan segala resiko, tantangan dan peluangnya. 
Seruan Apostolik Gaudete et Exultate yang dikeluarkan pada 19 Maret 2018 dan terdiri atas 5 bab dan 177 ayat ini, mengingatkan setiap orang akan panggilan kepada kekudusan. Panggilan itu berlaku untuk semua orang, masingmasing melalui jalannya sendiri (GE 14). Hal tersebut telah dibahas lebih dahulu oleh Lumen Gentium (bdk. LG 41). Secara berurutan, isi Geudete et Exultate adalah sebagai berikut: Bab Satu, Panggilan Kesucian, Orang Kudus yang memberi semangat dan menemani perjalanan orang Kristen. Bab Dua membahas tentang Dua Musuh Halus Kesucian (Two Subtle Enemies of Holiness). Bab ini menyinggung tentang Gnostisisme masa kini (Contemporary Gnosticism) dan Pelagianisme masa kini (Contemporary Pelagianism). Bab Tiga membahas tentang perlunya mencari dasar-dasar kukudusan yang sejati. Dalam bab ini dibahas tentang Terang sang Guru (In The Light of Master), dan ajakan untuk melawan arus (Going Against the Flow) serta membahas tetang kriteria yang luar biasa (The Great Criterion). Bab Empat membahas tentang tanda-tanda kekudusan di zaman ini (Signs of Holiness in Today's World). Paus Fransiskus menguraikan bahwa Sabda Bahagia dan norma-norma yang ditunjukkan dalam pengadilan terakhir adalah menjadi beberapa ciri kekudusan di dunia dewasa ini. Bab ini berisikan uraian tentang Ketekunan, Kesabaran, dan Kekerasan (Perseverance, Patience, and Meekness), bersukacita dan berselera humor (Joy and A Sense Humour), Keberanian dan Gairah (Boldness and Passion), Komunitas (In Community), dan doa yang konstan (In Constant Prayer). Bab Lima berisikan tentang Tempur Rohani, Kewaspadaan, dan Ketajaman (Spiritual Combat, Vigilance and Discernment). Kekudusan menuntut kita untuk terus menerus bergumul secara rohani, selalu waspada terhadap si jahat, untuk itu dibutuhkan penegasan rohani secara terus-menerus (Discernment).

Dalam Butir-butir Teologis dari 5 Gagasan Teologis Dasar pada Cita-Cita Ardas Keuskupan Surabaya, salah satu tema yang dicuatkan adalah tema "Muridmurid Kristus" (Kemuridan). Inti dari kemuridan sendiri tidak lain adalah bagaimana seseorang dipanggil Kristus menjadi murid-Nya dan kemudian menghayati kemuridan-Nya itu. Dalam membahas tema Kemuridan ini, ada 9 butir pokok pembahasan di antaranya adalah tema tentang kekudusan (dipanggil pada kekudusan). Tema ini menjadi bagian perjalanan ketika para murid Kristus menghayati panggilan sebagai murid yang harus mewartakan Injil dan menyatukan diri dengan Kristus dalam Ekaristi. Ketiga sakramen yaitu Baptis, Krisma dan Ekaristi merupakan sakramen-sakramen inisiasi Kristiani. Sakramensakramen itu meletakkan dasar untuk panggilan bersama semua murid Kristus, yakni panggilan pada kekudusan dan untuk membawa kabar gembira pada dunia. Sakramen-sakramen itu memberi rahmat yang dibutuhkan, supaya murid-murid Kristus hidup sesuai dengan Roh Kudus di dalam kehidupan ini, dalam peziarahan 
menuju tanah air abadi. Kekudusan menjadi bagian yang tak terpisahkan dari panggilan sebagai murid yang perlu dihayati sepanjang zaman.

\section{2 (What), Apa itu Kekudusan?}

Kekudusan merupakan keadaan atau sifat kudus, yang mengandung arti kebersihan atau kemurnian religius, yang sering disebut juga sebagai kesucian. Selain itu, kata Ibrani asli, qo'dhes, mengandung gagasan keadaan terpisah, eksklusif, atau disucikan bagi Allah, yang adalah kudus; keadaan dipisahkan bagi pelayanan kepada Allah (Naude, 1996: 877). Kekudusan menjadi salah satu dari sifat utama Allah yang menjadi ciri khas-Nya. Kekudusan adalah kasih yang sempurna, sehingga kekudusan dan kasih adalah sesuatu yang tidak terpisahkan, sebab Allah adalah Kudus (Im 19:2, Lk 1:49, 1 Ptr 1:15) dan Kasih (1 Yoh 4:10,16). Persatuan atau persekutuan dengan Allah adalah inti dari kekudusan (1 Kor 15:28), sebab Allah Tritunggal adalah contoh dari persekutuan kasih antara Bapa, Putera dan Roh Kudus. Allah yang telah memanggil semua manusia kepada kekudusan, telah juga menanamkan kemampuan pada manusia untuk mengasihi dan hidup di dalam persekutuan (Finlayson, 1992:617). Katekismus Gereja Katolik (KGK) 233, menegaskan bahwa Allah itu cinta kasih. Dalam diri-Nya, Allah menghayati misteri persekutuan cinta kasih antar pribadi, yaitu Pribadi Allah Bapa, Putera dan Roh Kudus. Seraya menciptakan umat manusia menurut citra-Nya sendiri, Allah mengukir panggilan dalam kodrat manusia pria dan wanita dan karena itu juga kemampuan serta tanggung jawab untuk hidup dalam cinta dan dalam persekutuan. Kekudusan adalah persekutuan dengan Allah dan sesama dalam kasih. Dengan mengasihi inilah manusia dapat menjadikan hidupnya berarti dan bahagia, sebab sejak semula memang Allah menciptakan manusia agar mereka beroleh kebahagiaan.

Lumen Gentium menghubungkan kekudusan dengan kesempurnaan cinta kasih (LG 40). Semua orang dipanggil kepada kekudusan dan semua dipanggil menjadi sempurna seperti Bapa di surga adalah sempurna (bdk. Mat 5:48). Manusia yang diciptakan menurut gambar Allah, baik itu para religius maupun kaum awam, yang menikah ataupun lajang, tua ataupun muda, semua dipanggil kepada kesempurnaan kasih yang disebut kekudusan itu (LG 39). Jadi semua orang Kristiani, bagaimanapun status atau corak hidup mereka, dipanggil untuk mencapai kepenuhan hidup Kristiani dan kesempurnaan cinta kasih.

Kekudusan diperoleh melalui pemenuhan hukum yang terutama, yaitu mengasihi Allah dan sesama (Mrk 12:30-31). Semua dipanggil untuk saling mencintai satu sama lain, seperti Kristus telah mencintai para murid-Nya (Yoh 13:34; 15:12) yang dicapai dengan mengikuti jejak Yesus Kristus sesuai dengan karunia yang diberikan kepada tiap-tiap orang untuk memberi kemuliaan bagi Allah dan pelayanan kepada sesama. Kasih kepada Allah dan sesama 
menjadi syarat mutlak sebagai pengikut Kristus (Yoh 13:35). Gaudete et Exultate menghubungkan kekudusan dengan "Sabda Bahagia" yang digambarkan oleh Yesus dalam Mat 5:1-12 (GE 67-95). Kekudusan merupakan gaya hidup yang dihubungkan dengan kehidupan sehari-hari. Dalam konteks ini kekudusan diidentikkan dengan yang "bahagia" dan yang "diberkati" (GE 64). Melalui Gaudete et Exultate, Paus Fransiskus menjelaskan masing-masing Sabda Bahagia yang dihubungkan dengan kekudusan. Kekudusan identik dengan menjadi miskin dihadapan Allah (GE 70), sama dengan Kritus telah menjadikan diri-Nya miskin (bdk. 2 Kor 8:9). Kekudusan juga berarti bereaksi dengan lemah lembut dan rendah hati (GE 74). Kelemahlembutan merupakan ungkapan lain dari kemiskinan batin seseorang yang menyerahkan diri kepada Allah. Orang yang lemah lembut akan menaruh kepercayaan kepada Tuhan, dalam seluruh aspek kehidupannya. Bereaksi dengan lemah lembut dan rendah hati menjadikan orang mengetahui bagaimana harus berkabung dengan orang lain. Dan itulah kekudusan (GE 76).

Mengungkapkan sikap yang tetap terhadap situasi orang lain hanya mungkin terjadi bila seseorang sungguh mengakui diri sebagai pribadi yang lapar dan haus akan kebenaran yang dihubungkan dengan persoalan keadilan. Keadilan sejati terjadi pada diri orang lain, ketika orang itu sendiri adil dalam membuat keputusan, terutama terhadap mereka yang miskin dan lemah, dan itulah kebenaran. Dalam konteks ini Paus Fransiskus menghubungkan kekudusan dengan sikap yang selalu lapar dan haus akan kebenaran (GE 79). Sikap adil atau lapar dan haus akan kebenaran mendorong seseorang untuk melihat dan bertindak dengan murah hati (GE 82). Kemurahan hati seseorang ditandai oleh keberanian memberi ampun secara berlimpah dan tanpa batas kepada sesama yang bersalah dan memohon ampun. Memberi ampun berarti menghasilkan ulang dalam kehidupan beberapa ukuran kecil kesempurnaan Allah yang mengampuni secara berlimpah (GE 81).

Sabda Bahagia berbicara tentang orang-orang yang hatinya sederhana, suci dan tidak tercemar, karena hati yang penuh cinta tidak mengenal apapun yang dapat mencelakakan, melemahkan, atau yang membahayakan kasih itu sendiri, inilah yang sering disebut dalam Alkitab sebagai hati yang baru (Yeh 36:26). Hati yang demikian perlu selalu dijaga (Am 4:23). Menjaga hati yang baru tidak lain adalah upaya terus menerus mengasihi Allah dan sesama, secara benar dan tidak hanya dalam kata (Mat 22:36-40). Menjaga hati terbebas dari semua yang menodai kasih, itulah kekudusan (GE 86). Menjaga hati terbebas dari semua yang menodai kasih adalah hati yang penuh kedamaian dan berusaha terus menerus menyebarkan kedamaian itu kepada lingkungan sekitarnya. Usaha ini memerlukan kerajinan yang menuntut adanya ketenangan, daya cipta, kepekaan dan keterampilan. Menabur perdamaian di lingkungan sekitar itulah kekudusan (GE 89). Upaya untuk menabur perdamaian tidak selalu mudah, dalam upaya ini 
seringkali seseorang harus menghadapi berbagai tantangan dan penganiayaan, tetapi hal itu harus dijalankan, sebab itulah jalan Injil (GE 92-93). Setiap orang, setiap hari dipanggil untuk menerima jalan Injil, meskipun itu dapat menyebabkan munculnya masalah baginya. Dan itulah kekudusan (GE 94).

Kekudusan bagi Paus Fransikus tidak dapat dipahami terpisah dari sikap dan tindakan seseorang kepada Allah di dalam kaum miskin yang menderita (Mat 25:31-46). Maka dari itu, kekudusan pertama-tama bukan kategori moral yang menyangkut kelakuan manusia saja, melainkan kategori teologal (ilahi), yang menentukan hubungan manusia dengan Allah (Bdk GE 95), ini tidak berarti bahwa kelakuan moral tidak penting. Apa yang dikhususkan bagi Tuhan, harus sempurna atau utuh (lih. Kel 12:5, Im 1:3, Rm 16:19), dan kesempurnaan manusia tentu terdapat dalam taraf moral kehidupan. Dalam konteks ini Yesus bersabda: "Hendaklah kamu sempurna sebagaimana Bapamu di surga sempurna adanya" (Mat 5:48). Panggilan kepada kekudusan merupakan sebuah proses (to be), yang harus diperjuangkan secara terus-menerus hingga akhir, meskipun hal ini merupakan tuntutan yang dapat melampaui kemampuan manusia.

Dari pihak manusia kekudusan hanya berarti tanggapan atas karya Allah itu, terutama dengan sikap iman dan pengharapan (lih. 1 Tim. 2:15). Sikap itu dinyatakan dalam segala perbuatan dan kegiatan kehidupan yang serba biasa. Kekudusan bukan sekedar soal bentuk kehidupan, melainkan sikap yang dinyatakan dalam hidup sehari-hari. Lebih lanjut Paus Fransikus menjelaskan bahwa, kekudusan terpancar dalam ketekunan, kesabaran dan kelemahlembutan (GE 112-121). Kekudusan juga terwujud dalam rasa sukacita dan penuh humor (GE 122-128). Kekudusan terpancar dalam keberanian dan gairah (GE 129-139), dalam komunitas (GE 140-146) dan dalam doa yang konstan (147-157). Dalam konteks ini, kekudusan meliputi kekudusan personal, sosial dan komunial, artinya kekudusan bukan hanya relasi personal manusia dengan Allah saja, tetapi juga relasi dirinya dengan sesama dan tindakan komunitasnya terhadap sesama (Hakh, 2014:139-140).

Dalam konteks Ardas Keuskupan Surabaya, Kekudusan mengandaikan semakin mendalamnya kesadaran diri sebagai murid yang dipanggil oleh Sang Guru Sejati dengan ditandai oleh Baptisan Suci. Seorang murid tidak cukup ketika dirinya menerima baptisan, melainkan terus menerus berproses menyadari baptisanya itu. Menyadari baptisannya, berarti menyadari diri sebagai murid Kristus yang dipanggil dan diutus (Mat 28:19-20). Murid Kristus harus menyadari bahwa dirinya dipanggil menjadi pewarta Injil melalui baik kata maupun sikap yang dinyatakan dalam hidup hariannya. Ia harus dengan sukacita pula dalam menjalankan tugas sebagai pewarta itu (GE, 122-139). Kekudusan sebagai murid Kristus juga ditandai oleh kematangan relasi dirinya dengan Allah dan sesama. Sang Guru Sejati telah memberi contoh bagaimana berelasi dengan mereka yang 
kecil dan tersingkirkan; orang sakit disembuhkan, orang lapar diberi makan, orang mati dihidupkan kembali dan lain sebagainya. Namun demikian, Yesus juga selalu membina relasi personal dengan Bapa-Nya (Mat 14:23, Mat 26:36, Luk 6:12; Mrk 1:35). Murid Kristus perlu menyadari bahwa dirinya tidak selamanya kuat. Murid Krisus perlu menggali kekuatan ilahi secara terus-menerus sebagai daya kekuatan dalam menjalankan tugas perutusan sebagai pewarta Injil dan perlunya menjaga kekudusan. Sebab di luar Kristus, para murid tidak akan dapat berbuat apa-apa (bdk. Yoh 15:4-5). Kesatuan antara murid Kritus dengan Guru Sejatiya dihayati secara penuh dalam Ekaristi. Ekaristi menjadi sumber dan puncak kehidupan murid-murid Kristus, yaitu Gereja.

\section{3 (Why), Mengapa Kekudusan itu Penting?}

Berbicara tentang kekudusan tidak bisa dilepaskan dari pribadi Allah yang berkehendak (Pardede, 2019:116). Sejak awal, Allah telah memikirkan jalan tertentu untuk setiap orang yang percaya. Allah tidak hanya berpikir bagi para rohaniwan yang disucikan atau mereka yang menjalani kehidupan kontemplatif saja. Setiap orang dipanggil untuk kekudusan (GE 14). Kekudusan, pertama-tama bukan kehendak manusia, melainkan kehendak Allah (1 Tes 4:3, Ef 1:4; 1 Pet 1:16), walaupun setiap orang mempunyai jalan dan status kehidupan yang berbeda-beda. Setiap orang dipanggil untuk hidup kudus dengan menerapkan kasih kepada Tuhan dan sesama (Mat 22:37-39; Mrk 12:30-31), sehingga mereka mencapai kepenuhan hidup Kristiani (lihat LG 40 dan 42). Semua orang beriman Kristiani diajak dan memang wajib mengejar kesucian dan kesempurnaan hidup mereka. Kekudusan adalah kehendak Allah, sebab Allah memandang kekudusan menjadi hal yang sangat penting. Dimana letak pentingnya? Melalui kekudusan itu, Allah berkehendak agar manusia yang sudah tercemar oleh dosa, dipulihkan dan disempurnakan, serta mampu mencapai kesatuan kembali dengan Allah (Sarumaha, 2019:1-2). Selanjutnya, kekudusan juga menjaga manusia agar tetap setia pada diri sendiri dalam tingkatan yang terdalam, bebas dari segala bentuk perbudakan dan menghasilkan buah-buah kebaikan bagi dunia (bdk. GE 15).

Konsili Vatikan II, di dalam dokumennya tentang Gereja (Lumen Gentium) menyerukan panggilan kekudusan untuk semua orang yang berkehendak baik:

“...Para pengikut Kristus dipanggil oleh Allah bukan berdasarkan perbuatan mereka, melainkan berdasarkan rencana dan rahmatNya. Mereka dibenarkan dalam Tuhan Yesus, dan dalam Baptis iman sungguh-sungguh dijadikan anak-anak Allah dan ikut serta dalam kodrat ilahi, maka sungguh menjadi suci. Maka dengan bantuan Allah mereka wajib mempertahankan dan mengembangkan dalam hidup mereka kesucian yang telah mereka terima. Oleh rasul mereka dinasehati, supaya hidup "sebagaimana layak bagi orang-orang kudus" (Ef 5:3); supaya “sebagai kaum 
pilihan Allah, sebagai orang-orang Kudus yang tercinta, mengenakan sikap belas kasihan, kemurahan, kerendahan hati, kelemah-lembutan dan kesabaran” (Kol 3:12); dan supaya menghasilkan buah-buah Roh yang membawa kepada kesucian (lih. Gal 5:22; Rom 6:22). Akan tetapi karena dalam banyak hal kita semua bersalah (lih. Yak 3:2), kita terus-menerus membutuhkan belas kasihan Allah dan wajib berdoa setiap hari: "Dan ampunilah kesalahan kami” (Mat 6:12). Jadi bagi semua jelaslah, bahwa semua orang Kristiani, bagaimanapun status atau corak hidup mereka, dipanggil untuk mencapai kepenuhan hidup Kristiani dan kesempurnaan cinta kasih...” (LG, 40)

Mencermati seruan Konsili Vatikan II tersebut, dapat ditemukan pentingnya kekudusan itu. Kekudusan diperlukan oleh manusia. Kekudusan dapat memperbaharui kehidupan agar semakin layak yang ditandai oleh sikap belas kasihan, kemurahan, kerendahan hati, kelemah-lembutan dan kesabaran. Di pihak lain, kekudusan diperlukan karena kenyataan manusia, yaitu sebagai pribadi yang sering jatuh dalam kesalahan. Setiap orang dipanggil untuk terus-menerus mencapai kepenuhan hidup Kristiani, yaitu kesatuan dengan Allah dalam kesempurnaan cinta kasih.

\section{4 (Who), Siapa yang Dipanggil kepada Kekudusan?}

Dalam Kristus, Gereja tidak dapat kehilangan kekudusannya, sebab Kristus sang Kepala Gereja menyerahkan diri baginya dan untuk menguduskannya (Ef 5:25-26). Dalam Gereja, semua anggota dipanggil kepada kekudusan (menjadi kudus), sesuai dengan panggilan hidup masing-masing (LG 39, 41 dan GE 10, 14). Kekudusan itu harus nyata dalam buah-buah rahmat yang dihasilkan oleh setiap anggota sebagai orang beriman dalam corak hidup dan keteladanan hidupnya. Intinya setiap anggota Gereja dipanggil kepada kekudusan, yaitu hidup seturut dengan nasihat Injil (LG 39).

Panggilan untuk menjadi kudus bukan hanya kewajiban beberapa orang saja, melainkan kewajiban setiap orang Kristen. Kekudusan pertama-tama bukan tergantung kepada kemampuan pribadi manusia, melainkan karena Allah. Memiliki kemampuan yang baik bukanlah ukuran bagi setiap orang untuk menjadi kudus. Kekudusan itu diperoleh semata-mata karena rahmat Allah (1 Tes 4:3). Manusia adalah ciptaan Allah dan sebagai ciptaan, mereka harus selalu berusaha dan berjuang hari demi hari untuk menyerupai Yesus Kristus, dengan selalu membuka diri dikuduskan oleh-Nya. Untuk mencapai kesucian ini, setiap orang dituntut memiliki relasi pribadi yang mendalam dengan Yesus, dan tanpa relasi itu, kekudusan hanya menjadi impian atau angan-angan belaka.

Mother Angelica menyampaikan pesan-pesan Injil berkaitan dengan kekudusan ini. Angelica sebagai mana dikutip oleh Listiati (2018), mengatakan 
bahwa, "Everyone is called to be holy. Don't miss the opportunity!" (Setiap orang dipanggil untuk menjadi kudus. Jangan lewatkan kesempatan ini!) Yang menjadi soal adalah bagaimana caranya untuk hidup kudus itu? Seruan Mother Angelica ini selaras dengan seruan seruan Gereja kepada semua orang, yang menjadi salah satu fokus utama dalam Konsili Vatikan II yaitu tentang pentingnya kekudusan (lih. Lihat Lumen Gentium bab V: Panggilan Umum Untuk Kesucian Dalam Gereja).

Lumen Gentium rupanya bersumber pada pernyataan Yesus sendiri sebagaimana ditulis oleh Injil Matius (Mat 5:38) yang mengatakan bahwa: "Karena itu, haruslah kamu sempurna, sama seperti Bapamu di sorga adalah sempurna.” Kesempurnaan yang dimaksud adalah kekudusan. Panggilan kepada kekudusan merupakan sesuatu yang sangat penting, karena sesungguhnya hanya dengan hidup dalam kekudusan inilah manusia dapat menemukan kebahagiaan sejati. Hanya dengan hidup kudus dalam kasih, manusia menemukan arti hidup yang sesungguhnya.

Dalam Seruan Apostolik Gaudete et Exsultate (Bersukacita dan Bergembiralah), Paus Fransiskus menyerukan kepadai orang modern, guna mengusahakan kekudusan dalam hidup sehari-hari, yang bersumber pada Sabda Yesus yang terdapat dalam Mat 5:12. Dalam konteks ini Paus Fransiskus menyerukan bahwa:

"... Karena Tuhan telah memilih kita masing-masing, supaya kita kudus dan tak bercacat di hadapan-Nya dalam kasih" (GE 2)

" ... panggilan kekudusan yang dialamatkan Tuhan kepada kita masing-masing, panggilan juga dialamatkan, secara pribadi, kepada kamu..." (GE 10)

"Untuk menjadi kudus tidak perlu menjadi uskup, imam atau kaum religius. Kita sering tergoda untuk berpikir bahwa kekudusan hanya bagi mereka yang dapat menarik diri dari urusan biasa guna menghabiskan banyak waktu untuk berdoa. Bukan itu masalahnya. Kita semua dipanggil untuk menjadi kudus dengan menjalani hidup kita dengan kasih dan dengan memberikan kesaksian dalam segala hal yang kita lakukan, di manapun kita berada" (GE 14)

Kutipan-kutipan tersebut menunjukkan bahwa panggilan kepada kekudusan ditujukan kepada setiap murid Kristus, tanpa memandang fungsi dan jabatan dalam Gereja. Mereka semua, baik imam maupun awan, mendapat panggilan yang sama dalam kekudusan (bdk. LG 40). Orang yang mengambil bagian dalam kekudusan menyadari bahwa melalui kekudusan ini, Allah mengutus umat-Nya untuk menjadi umat-Nya yang kudus, di dunia yang sudah tercemar oleh ketidak-kudusan. Melalui pengudusan, Allah tidak hanya mengutus mereka yang dipandang baik, melainkan juga mengutus manusia lain yang 
berdosa (Guthrie, 1995: 77). Ada misi yang diberikan oleh Allah kepada manusia yang merespon kekudusan dan menjadi tanggung jawab manusia untuk mengemban misi tersebut. Misi itu berkaitan dengan tujuan kekudusan itu sendiri. Tujuan dari kekudusan adalah mengembangkan, menjaga dan menampilkannya melalui tindakan nyata dalam hidup sehari-hari, apa yang terkandung dalam kekudusan itu sendiri, yaitu menyatakan kemuliaan Allah dan keselamatan manusia secara untuh.

Dari uraian tersebut di atas, dapat dipahami bahwa semua orang Kristiani, bagaimanpun statusnya (awam dan hierarki) atau corak hidup mereka (GE 14), dipanggil kepada kekudusan, yaitu mencapai kesempurnan hidup Kristiani atau kesempurnaan cinta kasih berdasarkan nasihat Injil (LG 39). Diharapkan bahwa kekudusan menjadi sarana yang sangat ampuh untuk menjadikan manusia semakin manusiawi (LG 40). Masing-masing anggota Gereja dipanggil secara terus-menerus bertumbuh dan menghasilkan buah berlimpah, seperti dalam sejarah Gereja telah terbukti secara mengagumkan melalui teladan hidup para kudus.

Sebagai seorang iman perlu menghayati kekudusan secara khas sebagai selibater dan sebagai pelayan umat. Dalam konteks ini selibat dihayati sebagai karisma dan wujud pelayanan. Selibat sebagai karisma yang diterima dari Allah ditujukan pada karya pelayanan Gereja. Paulus pernah mengatakan bahwa setiap pribadi memiliki karisma masing-masing untuk melayani Gereja. Karisma tersebut diterima dan dihayati sebagai komitmen untuk memberikan dirinya secara total bagi kebutuhan Gereja. Hal yang terkait langsung dengan hal karisma adalah pilihan hidup. Pilihan hidup selibat sekaligus menjadi kesaksian untuk bersedia mendedikasikan diri untuk pelayanan dengan hati tak terbagi. Hidup selibat mengandung suatu keterbukaan untuk melayani kebutuhan Gereja universal, termasuk kebutuhan masyarakat. Selibat tidak menjadikan seorang imam menutup diri atas kebutuhan orang lain, tetapi justru memampukan dirinya untuk terbuka kepada realitas dan kebutuhan di luar dirinya. Dengan demikian, hidup selibat merupakan pilihan hidup yang tepat untuk para imam.

Sebagai pelayan umat, kaum iman perlu hidup dalam cinta. Hidup selibat bukanlah suatu pilihan hidup untuk berhenti mencinta, tetapi merupakan cara yang radikal dalam mencintai. Cinta yang diungkapkan di sini semata-mata tidak didasari oleh dorongan naluriah seksual yang melihat sesama sebagai objek seksual, tetapi didasari penghargaan atas keutuhan pribadi orang lain yang juga memiliki sisi keilahian di dalam dirinya. Cinta dalam hidup selibat berarti mencintai dengan sepenuh hati seperti Yesus sendiri mencintai sesama, dan sekaligus mencintai Yesus yang ada di dalam diri sesama. Pelayanan merupakan suatu wujud pemberian diri yang total seorang imam kepada Gereja. Karya pelayanan seorang imam merupakan upaya untuk mengembangkan sisi afektifnya. 
Sisi afektif tersebut diungkapkan dalam karya pelayanan yang penuh belas kasih kepada Gereja-Nya. Sikap berbelas kasih (compassion) berarti menempatkan diri pada posisi orang lain, turut merasakan penderitaannya seolah-olah menjadi penderitaan sendiri, dan dengan murah hati masuk ke dalam sudut pandangnya. Dalam konteks ini imam harus terus-menerus menyatukan diri dengan Kristus, dalam hidup doa, istimewanya Ekaristi. Imam ditahbiskan untuk diutus. Perutusan imam terkait dengan tugas imamat yang telah lebih dahulu dijalankan oleh Imam Agung yaitu Yesus Kristus. Sebelum menjalankan tugas perutusan itu, seorang imam perlu menghayati perstuan dirinya dengan Yesus Kristus.

Awam dipanggil kepada kekudusan terutama melalui penghayatan hidup dalam membina keluarga. Melalui relasi diri dengan pasangan dan anggota keluarga yang lain serta dinamika dengan masyarakat umum, awam dipanggil kepada penghayatan diri sebagai murid Kristus yang terus-menerus diutus dan senantiasa menyatukan diri dengan Sang Guru Sejati. Allah memanggil dan mengutus para pekerja, terutama kaum awam untuk menata dunia atau kebun anggur melalui berbagai usaha menata mengatur kehidupan keluarga, dunia pendidikan, ekonomi, politik, hukum, sosial, budaya dan lain-lainnya seturut kehendak dan rencanaNya. Alasan menata kehidupan dunia sehari-hari sesuai kehendak Allah, yaitu supaya setiap kegiatan yang dilakukan dapat menjadi tanda kasih, berkat dan kebaikan Allah untuk banyak orang. Allah menghendaki agar setiap awam yang terlibat dalam kegiatan dan pelayanan di lingkungan sekolah, kantor, organisasi, perkumpulan baik swasta maupun pemerintah dapat menjadi tanda kasih, kebaikan atau berkat Allah untuk banyak orang. Karena itu, setiap umat beriman, terutama kaum awam selalu perlu bertanya kepada diri sendiri tentang sudah sejauh mana pekerjaan dan pelayanan yang dikerjakan sehari-hari sudah menjadi tanda berkat dan kebaikan Allah bagi banyak orang?

Undangan bagi awam untuk bekerja di Kebun Anggur terus datang dan bergema. Undangan ini menuntut respon positif yang diungkapkan antara lain melalui keterbukaan para awam terhadap bimbingan Roh Kudus untuk memahami dan segera menyikapi tanda-tanda zaman, peristiwa-peristiwa hidup, harapan, kecemasan dan kerinduan manusia sesuai kehendak Tuhan. Iman kepada Allah menuntut awam untuk membaca serta mewujudkan rencana dan kehendak Allah dalam setiap peristiwa konkret, tanda-tanda zaman, harapan dan kecemasan hidup manusia (Bdk. GS. 7). Awam diutus menjadi terang dan garam dunia, karena dunia yang penuh dengan berbagai kesibukan hidup dan terus mengalami perubahan ini selalu membawa berbagai pengalaman hidup susah dan senang, menang dan kalah, gelap dan terang yang datang secara silih berganti dan bahkan bersamaan. Kitab Suci mengatakan bahwa gandum dan tanaman liar sering tumbuh bersama-sama di ladang (Mat 13:26). Artinya pengalaman hidup susah 
dan senang, menang dan kalah, terang dan gelap sering datang silih berganti dan bahkan bersamaan.

Sedangkan kaum religius dipanggil dalam kekudusan dengan menghayati hidup sebagai pilihan hidup karena Kerajaan Allah (Mat 19:12). Panggilan kepada kekudusan oleh kaum religius dihayati melalui kaul mereka, yaitu: kemurnian, kemiskinan dan ketaatan. Secara umum melalui ketiga kaul itu, para religius berusaha untuk menyerahkan diri sepenuhnya kepada Tuhan sehingga dapat digunakan oleh Tuhan. Intinya adalah menyatukan diri dengan Tuhan sendiri secara penuh. Kaul kemurnian atau keperawanan para religiustidak terikat dengan keluarga, seluruhnya hanya untuk Tuhan. Dengan kaul kemiskinan para religius tidak mau diikat oleh harta benda duniawi tetapi mau lebih bebas melekatkan diri pada Tuhan. Dan dengan kaul ketaatan para religius tidak mau terikat dengan kedudukan dan kekuasaan tetapi justru ingin taat pada perintah Tuhan sendiri.

\section{5 (When-Where), Kapan dan Di Mana Panggilan kepada Kekudusan itu Dihidupi?}

Seruan Apostolik Gaudete et Exultate mendasarkan diri pada Sabda Yesus yang dinyatakan dalam Mat 5:12, yaitu: "Bersukacita dan bergembiralah, karena upahmu besar di sorga." Paus mengambil Sabda Yesus (Khotbah di Bukit) ini sebagai seruan bagi orang modern, guna mengusahakan kekudusan dalam hidup sehari-hari dan menjalankan Sabda Bahagia yang telah Yesus wariskan kepada para murid-Nya (lih. GE 63-64). Panggilan kekudusan dijalankan ketika seseorang mulai melaksanakan perintah Allah (Rom 7: 12). Perintah ini mencakup hidup seseorang di dalam iman, harapan dan kasih, terutama perintah untuk mengasihi Allah di atas segalanya dan mengasihi sesamanya (Mat 22: 37-39; Mrk 12:30). Dengan cara ini seseorang dapat menjadi kudus dan tak bercela di hadapan Tuhan (Fil 1:10, 1 Tes 3:12). Mengasihi berarti menjadikan kasih sebagai sesuatu yang utama dalam hidup seseorang.

Panggilan kepada kekudusan dijalankan ketika orang berani menanggalkan manusia lama dan siap dengan manusia baru. Meninggalkan manusia lama adalah konsekuensi dari pembaptisan yang telah diterimanya. Dengan melaksanakan semua ini, orang dapat hidup di dalam kebenaran dan bertumbuh di dalam kekudusan untuk menjadi semakin serupa dengan Allah (Ef 4:22-24). Panggilan kepada kekudusan dijalankan ketika orang berusaha meneladan Allah yang kudus dan sempurna (1 Pet 1:15-16; Mat 5:48), melalui teladan Kristus untuk diterapkan di dalam perkataan, pikiran dan perbuatannya. Setiap orang perlu berjuang keras untuk menerapkan hal ini, sebab memang tidak mudah untuk dapat hidup kudus dalam zaman dewasa ini, terlebih dengan adanya banyak godaan yang menarik untuk melakukan dosa. Panggilan kepada kekudusan semakin nyata ketika orang 
berusaha mengembangkan tiga pola hidup Injili yaitu, kesucian (chastity), kemiskinan (poverty) dan ketaatan (obedience).

Menurut Santo Fransiskus de Sales, hidup kudus diawali oleh pemurnian dari dosa (pertobatan) melalui pengakuan dosa. Tahap selanjutnya adalah dengan pemurnian suara hati, sehingga seseorang dapat memiliki rasa penyesalan yang sungguh dan membuat niat yang teguh untuk memperbaiki diri secara terusmenerus (Listiati, 2018). Menurut Paus Fransiskus, kekudusan itu diperoleh dan dihidupi dalam hubungannya dengan hidup sehari-hari. Kekudusan tidak hanya untuk mereka yang dapat mengundurkan diri dari urusan duniawi dan menghabiskan banyak waktu dalam doa, tetapi terutama untuk mereka yang berani memberi kesaksian hidup tentang Kristus melalui hidup iman dan cinta kasih (GE 8). Setiap orang dipanggil menjadi suci dengan menjalani hidup dengan cinta dan memberikan kesaksian dalam segala hal yang dilakukan, di mana pun ia berada (GE 14). Lebih lanjut Paus Fransiskus menjelaskan bahwa tempat untuk menghidupi kekudusan tidak lain adalah juga tempat di mana sesorang menghidupi panggilannya. Dalam Gaudete et Exultate, Paus Frasiskus menyebut beberapa bentuk panggilan hidup antara lain misalnya: dipanggil untuk hidup bakti, dipanggil untuk menikah, dipanggil sebagai pekerja, dan dipanggil sebagai orang tua atau kakek-nenek. Melalui panggilan hidup itu, mereka diharapkan dapat menjalankan tugas dan panggilannya dengan penuh tanggung jawab dan sukacita, sebagai upaya menjalankan hidup dalam kasih. Di sanalah kekudusan itu dijalankan dan ditumbuh-kembangkan (GE 14 bdk. LG 40-41). Segala sesuatu dapat disatukan dengan kehidupan di dunia dan bahkan segala sesuatu itu menjadi bagian yang tak terpisahkan dari upaya manusia menuju kekudusan. Setiap orang dipanggil menjadi pendoa termasuk melalui tindakan nyata sehari-hari. (GE 26 bdk LG 41).

Kaum imam (klerus) berusaha menghayati kekudusannya melalui pelayanan kepada umat di mana para imam diutus. Secara khusus dan khas, panggilan kekudusan ini dihayati para iman ketika mereka menjalankan reksa pastoral di tempat mereka ditugaskan, dan menghayati diri sebagai kaum selibater di tengah umat. Reksa pastoral (pastoral engeenering) seorang imam memerlukan kelembutan dan cinta. Bagaimana seorang iman sungguh menghayati makna pelayanan pastoral, menjadi ruang dan waktu agar panggilan kekudusan dapat dihayati dan diwujud-nyatakan. Kedua hal, yaitu selibat dan pelayanan pastoral merupakan dua sisi yang saling terkait dan saling mengisi. Selibat merupakan kesaksian hidup yang mewartakan tentang totalitas pengabdian diri kepada Allah dan sesama. Totalitas tersebut adalah pesan yang menjadikan selibat adalah pilihan hidup yang berharga dan bermakna. Kesaksian mengenai hidup selibat akan semakin menginspirasi umat beriman, jika para imam menghayatinya dengan gembira. Selibat merupakan pilihan hidup yang membahagiakan untuk 
mencintai dan mengabdi Allah melalui pelayanan yang total kepada sesama. Dengan melihat kebahagiaan seorang imam dalam melaksanakan hidup selibat, umat beriman terpanggil untuk mendukung hidup selibat, meskipun dibutuhkan kesetiaan dan perjuangan untuk menjalaninya.

Kaum awam memiliki ruang dan waktu untuk menghayati atau menghidupi panggilan kekudusan dalam dunia yang khas bagi mereka, yaitu: keluarga, masyarakat umum dan dunia karya mereka. Allah memanggil dan mengutus awam untuk menata dunia melalui berbagai upaya mengatur tata kelola kehidupan keluarga, dunia pendidikan, ekonomi, politik, hukum, sosial, budaya dan lain-lainya seturut kehendak dan rencanaNya dengan tujuan supaya kasih, berkat dan kebaikan Allah itu dapat dialami banyak orang. Di tengah dunia yang sekularistik, awam sebagai Gereja Umat Allah diundang untuk terlibat aktif dalam tata kelola dan pembaharuan dunia seturut kehendak dan rencana Allah. Awam terpanggil untuk mengambil bagian dalam tata kelola dunia yang berdimensi sekularistik atas cara berbeda. Panggilan ini harus direspon dengan penuh iman dan sukacita.

Wujud konkret fungsi awam menata dunia ini dinyatakan melalui berbagai profesi, pekerjaan atau kegiatan awam sehari-hari dalam bidang sosial, budaya, pendidikan, politik, ekonomi, hukum, pemerintahan dan lain-lain. Semua kegiatan ini perlu dilakukan selaras dengan rencana dan kehendak Allah demi kebaikan dan keselamatan universal. Martabat hidup awam sebagai umat beriman selain terletak pada panggilan Allah dan jawaban atas panggilan Allah untuk menata dunia ini, juga terletak pada panggilan untuk menghayati kekudusan, kesempurnaan dan kebaruan hidup. Menghayati kekudusan, kesempurnaan dan kebaruan hidup merupakan suatu tuntutan fundamental bagi awam karena kekudusan, kesempurnaan dan kebaruan hidup ini merupakan dasar kesatuan hidup umat beriman dengan Allah Bapa dan Yesus Kristus Putra Allah.

Kaum Religius dengan kekhasan tiga kaulnya, bukan berarti terlepas sama sekali dari dunia nyata, tak terkecuali kaum religius kontemplatif. Kaum religius kontemplatif berusaha menghayatai kekudusan melalui cara hidup yang mengutamakan kehidupan penuh ketenangan, bermati raga dan bertapa. Melalui cara hidup dan doa mereka ini, menjadi sarana untuk menyelamatkan dunia. Sedangkan kaum religius non kontemplatif, mengusahakan pengudusan melalui karya-karya mereka di mana mereka memiliki konsentrasi karya, misalnya: Panti Asuhan, Rumah Sakit atau Poliklinik, Sekolah dan sebagainya. Kehadiran Krsitus dalam Gereja akan semakin tampak melalui kesaksian para religius dalam hubungannya dengan masyarakat secara nyata. Kehadiran itu merupakan upaya untuk membangun dunia secara lebih baik. Panggilan kesucian ini hendaknya tetap diperjuangkan oleh para religius sehingga melalui cara hidup mereka berkomunitas dan berkarya menjadi kesaksian yang konkret dan semakin 
memperindah wajah Gereja. Dengan mengikrarkan nasihat-nasihat Injil, para religius bukan hanya melepas tawaran dunia, tetapi juga mengorbankan hal-hal yang pantas dan memiliki makna yang teramat tinggi. Ketika para religus memberi kesaksian hidup di tengah komunitasnya dan dunia karya mereka, saat itu mereka mengupayakan dan memperjuangkan kekudusan.

\section{6 (How), Bagaimana Panggilan kepada Kekudusan Harus Diupayakan dan Dijalankan?}

Panggilan kepada kekudusan adalah bentuk panggilan yang tidak dapat dilepaskan dari kesatuan Gereja dengan Kristus sendiri (LG 39). Panggilan kepada kekudusan hanya akan dapat dihidupi secara berdaya guna bila panggilan itu juga berpusat pada Kristus, dalam gerakan Roh Kudus dan dalam kesatuan dengan kasih Bapa (LG 41). Kristus sendiri lebih dahulu telah memberi teladan kekudusan dengan menjadi miskin, rendah hati dan memanggul salib-Nya agar manusia pantas ikut menikmati kemuliaan-Nya. Inti dari tindakan Kristus adalah tindakan cinta (LG 42). Oleh karena itu, menghayati kekudusan berarti pula menghayati hidup dalam cinta. Sebab dengan cinta, seseorang tanpa ragu-ragu menempuh jalan iman yang hidup, yang membangkitkan harapan dan mewujudkan diri. Semua orang beriman Kristiani dalam kondisi-kondisi hidup atau dalam tugas-tugas serta keadaan masing-masing, dipanggil untuk memperjuangkan dan sekaligus mengungkapkan kekudusan. Hal itu hanya mungkin terjadi bila mereka dalam iman menerima segala sesuatu dari tangan Bapa dan bekerjasama dengan kehendak ilahi, dengan menampakkan melalui tugas sehari-hari sebagai ungkapan cinta kasih Allah terhadap dunia (LG 41).

Dalam Seruan Apostolik "Gaudete et Exsultate", Paus Fransiskus menyampaikan pokok-pokok hidup Kristiani yang berkaitan dengan kekudusan itu. Pokok-pokok hidup Kristiani tersebut oleh Pastor James Martin SJ diberi judul: "Top Five Take aways from 'Gaudete et Exsultate'" atau Lima Jalan Menuju Kekudusan Menurut 'Gaudete et Exulate' (Bilandoro, 2018). Pokokpokok hidup Kristiani yang dimaksud adalah adalah: 1) kekudusan berarti menjadi diri sendiri, 2) kehidupan sehari-hari dapat memimpin kita kepada kekudusan, 3) menghindari dua kecenderungan utama: Gnostisisme dan Pelagianisme, 4) bersikap baik dan 5) Sabda Bahagia adalah penunjuk jalan menuju kekudusan.

\subsubsection{Kekudusan berarti Menjadi Diri Sendiri}

Paus Fransiskus menawarkan banyak contoh kehidupan suci, misalnya: St. Theresia dari Lisieux (Karmelit Prancis yang menemukan kekudusan dalam melakukan tugas-tugas kecil), St. Ignatius dari Loyola (pendiri Yesuit yang mencari Tuhan dalam segala hal), dan St. Philip Neri pendiri Oratorians (yang terkenal karena selera humornya). Menurut Paus Fransiskus, orang-orang kudus 
berdoa bagi kita dan memberikan teladan mengenai bagaimana kita hidup, tetapi orang Kristen tidak perlu menjadi "penggalan” atau "salinan” dari orang-orang kudus tersebut. Setiap orang Kristen perlu menjadi diri sendiri (GE 11). Mereka perlu membedakan jalannya sendiri dan memunculkan yang terbaik dari dirinya sendiri (GE 12). Menjadi orang suci berarti menjadi diri sendiri.

\subsubsection{Kehidupan Sehari-hari dapat Memimpin Kita kepada Kekudusan}

Bagi Paus Fransiskus, seseorang tidak perlu menjadi uskup, imam, atau anggota ordo religius untuk menjadi suci. Setiap orang dipanggil untuk menjadi orang suci, sebagaimana dikatakan Konsili Vatikan II, entah sebagai seorang ibu atau ayah, seorang siswa atau seorang pengacara, seorang guru atau petugas kebersihan (GE 14 bdk. LG 41). Dalam GE 6-9, Paus menyebut mereka ini sebagai “Saints next door” (orang-orang kudus "pintu sebelah"). Bagi Paus, yang perlu dilakukan adalah menjalani hidup di dalam cinta dan memberi kesaksian tentang Tuhan melalui setiap tindakan yang dilakukan.

"We are frequently tempted to think that holiness is only for those who can withdraw from ordinary affairs to spend much time in prayer, that is not the case. We are all called to be holy by living our lives with love and by bearing witness in everything we do, wherever we find ourselves" (Bilandoro, 2018)

"Kita sering tergoda untuk berpikir bahwa kekudusan hanya bagi mereka yang dapat menarik diri dari urusan biasa untuk menghabiskan banyak waktu dalam doa, itu tidak terjadi. Kita semua dipanggil untuk menjadi kudus dengan menjalani hidup kita dengan cinta dan dengan memberikan kesaksian dalam segala hal yang kita lakukan, di mana pun kita berada”

Mencermati kutipan di atas, dapat dipahami bahwa kekudusan dapat digapai melalui kehidupan biasa bahkan melalui kehidupan yang paling senderhana sekalipun. Untuk menjadi kudus, orang tidak harus melakukan tindakan besar dan dramatis, melainkan cukup melalui kehidupan konkret seharihari. Paus Fransiskus menawarkan contoh kesucian dalam hidup sehari-hari, misalnya: orangtua yang penuh kasih membesarkan anak-anak mereka, memutuskan untuk tidak meneruskan gosip, menghindari berbicara buruk tentang siapapun, bersedia mendengarkan keluh kesah orang lain dengan sabar dan cinta, serta ramah kepada orang miskin dan sebagainya (bdk. GE 16).

Paus juga menegaskan bahwa apabila seseorang dapat melihat kehidupannya sendiri sebagai misi, maka orang tersebut akan segera menyadari bahwa dirinya dapat dengan penuh kasih dan baik hati bergerak menuju kekudusan. Jadi seseorang tidak harus berlelah-lelah sampai pingsan dalam mengusahakan hidup mistik dan juga tak perlu harus mengundurkan diri dari 
orang lain, tetapi cukup dengan menjalani hidup yang seharusnya dijalani (GE 26). Di sisi lain, orang tidak perlu terjebak dalam suatu perlombaan yang terburu-buru dari satu hal ke hal lainnya. Hal terpenting untuk mengusahakan kekudusan dalam hidup sehari-hari, menurut Paus Fransiskus, adalah keseimbangan antara tindakan dan kontemplasi (GE 29)

\subsubsection{Menghindari Dua Kecenderungan Utama: Gnostisisme dan Pelagianisme}

Hal pertama yang harus dihindari adalah Gnostisisme. Paham ini berasalusul dari kata Yunani "gnosis", berarti mengetahui. Dalam sejarah Gereja, Gnostisisme adalah ajaran sesat yang mengatakan bahwa yang paling penting adalah apa yang diketahui. Paham ini menolak tindakan amal atau perbuatan baik. Paham ini menegaskan bahwa yang dibutuhkan manusia hanyalah pendekatan intelektual yang benar (GE 36). Gnostik gagal menyadari bahwa kesempurnaan manusia pertama-tama diukur oleh kedalaman amalnya, bukan oleh informasi atau pengetahuan baiknya. Memisahkan intelek dari tindakan, berarti mengurangi kebenaran yang Yesus ajarkan kepada murid-murid-Nya. Pengalaman Kristen bukanlah seperangkat latihan intelektual. Demikian juga Kearifan Kristen sejati tidak akan pernah bisa dipisahkan dari belas kasih terhadap sesama manusia. Paus Fransiskus mengatakan bahwa dewasa ini Gnostisisme menggoda orang untuk berpikir bahwa mereka dapat membuat iman "sepenuhnya dapat dipahami” dan menuntun mereka untuk memaksa orang lain mengadopsi cara berpikir mereka (GE 40-41).

Hal kedua yang harus dihindari adalah Pelagianisme. Paham ini berasal dari Pelagius, seorang teolog abad ke-5. Pelagianisme adalah paham yang mengatakan bahwa manusia dapat mencapai keselamatan melalui upaya manusia sendiri (GE 48). Pelagian mempercayai kekuatan diri sendiri, serta bertindak lebih superior daripada yang lain karena mematuhi aturan tertentu, dan merasa tidak membutuhkan rahmat Tuhan (bdk. GE 49). Pelagian modern menunjukkan bahwa kehendak manusia adalah sesuatu yang murni, sempurna dan mahakuasa. Mereka gagal menyadari bahwa hidup manusia pada hakikatnya membutuhkan rahmat Tuhan (bdk Ef 2:8). Paus Fransiskus mengatakan Pelagianisme dewasa ini sering kali memiliki apa yang disebut sebagai "obsesi terhadap hukum, penyerapan dengan keuntungan sosial dan politik, perhatian penuh terhadap liturgi gereja, doktrin, dan prestise.” Ini adalah bahaya nyata bagi kekudusan, karena mereka merampok manusia dari kerendahan hati dan menempatkan manusia di atas orang lain, serta memberikan sedikit ruang untuk peranan rahmat Allah (GE 50 dan 58). 


\subsubsection{Bersikap Baik}

Melalui Seruan Apostolik “Gaudete et Exsulatate”, Paus memberikan nasihat praktis bagi umat zaman modern untuk menjalani kehidupan menuju kepada kekudusan. Paus mengatakan, misalnya: jangan bergosip, hentikan sikap memberi penilaian, dan yang paling penting berhenti bersikap kejam (bdk GE 16). Nasihat berbuat baik ini juga berlaku untuk kegiatan online. Secara online, Paus menulis:

"Fitnah dan umpatan bisa menjadi hal yang biasa, karena hal-hal dapat dikatakan di sana, tidak dapat diterima dalam wacana publik, karena orang-orang mencari untuk mengimbangi ketidakpuasan mereka sendiri dengan menertawakan atau memukul orang lain. Dalam mengklaim untuk menegakkan perintah-perintah lain, mereka benar-benar mengabaikan Perintah Allah kedelapan, yang melarang membuat saksi palsu atau berbohong dan dengan kejam memfitnah orang lain.” (Bilandoro, 2018)

Dari pernyataan tersebut di atas dapat disimpulkan bahwa menjadi suci, berarti berbuat baik, dan perbuatan baik akan semakin nyata ketika seseorang menghadapi fitnah dan umpatan dalam kehidupanya. Pernyataan tersebut menjelaskan bahwa perbuatan manusia semakin nampak baik ketika seseorang berani berkata benar dan melakukan kebaikan juga pada saat menghadapi kesulitan serta tantangan.

\subsubsection{Sabda Bahagia adalah Penunjuk Jalan Menuju Kekudusan}

Kekudusan itu bukan sekedar apa yang dimaksudkan Yesus melalui pewartaan-Nya, melainkan kekudusan adalah potret Tuhan Yesus sendiri. Untuk menjadi kudus setiap murid Kristus dipanggil untuk menjadi miskin dalam roh, takut akan Allah, menjadi pembawa damai, haus dan lapar akan kebenaran, dan seterusnya (GE 67-94). Paus Fransiskus sendiri mengatakan: Berbahagialah orang yang berbelas kasih, mereka yang hatinya sederhana, suci dan tidak tercemar, hati yang mampu mengasihi tanpa membatasi diri kepada siapa harus mengasihi (GE 83 dan 86). Belas kasihan sebagai salah satu tema sentral kepausannya, memiliki dua aspek yakni membantu dan melayani orang lain, tetapi juga memaafkan dan memahami mereka yang memerlukan perhatian.

Setiap Sabda Bahagia, terdiri atas tiga bagian, yaitu: kata pembukaan "Berbahagialah", yang diikuti oleh situasi tempat mereka yang disebut diberkati atau berbahagia menemukan diri mereka, miskin dalam roh, berduka, haus akan keadilan, dan akhirnya diteruskan dengan alasan mereka diberkati atau berbahagia. Ada delapan Sabda Bahagia dan akan indah ketika dipelajari dan diulangi dengan hati, agar hukum yang diberikan oleh Yesus kepada para muridNya, tetap dalam pikiran dan hati. Sabda Bahagia juga mengajarkan bahwa yang para murid diberkati bukan oleh situasi saat ini (situasi berdosa atau hilangnya 
rahmat), melainkan oleh kondisi baru yang menjadi milik para murid oleh rahmat Allah. Berbahagia menunjuk kepada situasi jalan yang ditunjuk Allah yaitu: kesabaran, kemiskinan, pelayanan terhadap orang lain dan penghiburan. Orang yang mau masuk dalam jalan itu akan berbahagia atau akan diberkati.

\section{PENUTUP}

Dipanggil kepada kekudusan dalam konteks ini lebih cocok diartikan sebagai dipanggil untuk menjadi kudus (to be holy). Kudus merupakan salah satu dari sifat utama Tuhan dan menjadi ciri khas-Nya. Kekudusan sendiri memiliki muatan sebagai kasih yang sempurna, sehingga kekudusan dan kasih adalah sesuatu yang tidak terpisahkan. Allah adalah Kudus (Im 19:2, Lk 1: 49, 1 Ptr 1:15) dan Kasih (1 Yoh 4: 10, 16). Persatuan manusia dengan Allah adalah inti dari kekudusan. Kekudusan memiliki hubungan dengan kesempurnaan cinta kasih, maka kekudusan tidak dapat dipahami secara terpisah dari sikap dan tindakan seseorang kepada Allah dalam kasih, melalui tindakan kasih kepada kaum miskin yang menderita. Kekudusan merupakan gaya hidup yang dihubungkan dengan kehidupan sehari-hari seturut dengan Sabda Bahagia yang Yesus sampaikan kepada murid-murid-Nya. Kekudusan itu harus nyata dalam buah-buah rahmat yang dihasilkan oleh setiap anggota sebagai orang beriman dalam corak hidup dan keteladanan. Setiap anggota Gereja dipanggil kepada kekudusan, yaitu hidup seturut dengan nasihat Injil.

Panggilan untuk menjadi kudus bukanlah menjadi kewajiban dari beberapa orang saja, melainkan kewajiban setiap orang Kristen. Kekudusan itu diperoleh dan dihidupi dalam hubungannya dengan hidup sehari-hari, dalam menghayati cinta. Kekudusan dapat diupayakan melalui: menjadi diri sendiri, membiarkan diri dipimpin oleh kehidupan sehari-hari, menghindari dua kecenderungan utama (Gnostisisme dan Pelagianisme), bersikap baik dan melalui penghayatannya terhadap Sabda Bahagia. Kekudusan, pertama-tama bukan kehendak manusia, melainkan kehendak Allah. Allah menghendaki kekudusan agar manusia yang sudah tercemar oleh dosa, dipulihkan dan disempurnakan serta mampu mencapai kesatuan kembali dengan Allah. Melalui penghayatan sebagai orang yang dibaptis, dikuatkan dalam Sakramen Krisma dan disatukan dengan Kristus dalam Ekaristi, para murid Kristus dipanggil ke dalam kekudusan dalam kesatuan dengan kehidupan konkret sehari-hari, berdasarkan kekhasannya masing-masing. 


\section{DAFTAR PUSTAKA}

\section{A. Buku dan Dokumen dan:}

----------, 2009, Alkitab Deuterokanonika, Jakarta: Lembaga Alkitab Indonesia.

Donald Guthrie,1995, Teologi Perjanjian Baru-I, Jakarta: BPK-GM.

Finlayson, R.A., 1992, Kudus dalam Ensiklopedia Alkitab Jilid I, J.D. Douglas, Jakarta: YKBK.

Fransiskus, Paus, 2018, Gaudete et Exsultate, dalam KWI (Februari 2019), Seri

Dokumen Gerejawi No 106, Bersukacita dan Bergembiralah, Jakarta:

Departemen Dokumentasi dan Penerangan Koferensi Waligereja Indonesia.

Hardawiryono, R, SJ (Terj), 2017 (Cet. ke 13), Dokumen Konsili Vatikan II, Jakarta: Dokumentasi dan Penerangan KWI - Obor.

Naude, Jackie A., 1996, dalam Willem A. Vangemerem (Author), Dictionary of Old Testament Theology \& Eksegesis, Paternoster Press.

Vaticana, Liberia Editrice, 2014, Katekismus Gereja Katolik, dalam P. Herman Embuiru (Terj), Ende-Flores: Nusa Indah.

\section{B. Jurnal:}

Hakh, Samuel, Benyamin, 2014, "Kuduskanlah Kamu, Sebab Aku Kudus" dalam Jurnal Teologi, Sola Experentia, Vol. 2, No. 2, Oktober 2014.

Kulsum, Ummu, Abdul Munib, 2017, "Penerapan Model Pembelajaran Probing Question (PPQ) Untuk Meningkatkan Kreativitas Siswa di Kelas Tingkat Sekolah Dasar", dalam Jurnal JPSD, Vol. 4, No 1, Th 2017.

Pardede, Zulkisar, 2019, "Rancang Bangun Teologi 'Kekudusan' Tentang Hamba Tuhan Sebagai Pemimpin Kristen Menurut Kitab Yosua", dalam Kharismata, Jurnal Teologi Pantekosta, Volume 1, No 2, Januari 2019 (100-117).

Sarumaha, Nurnilam, 2019, "Pengudusan Progresif Orang Percaya Menurut 1 Yohanes 1:9" dalam Kurios (Jurnal Teologi dan Pendidikan Agama Kristen), Vol. 5, No. 1, April 2019 (1-11).

\section{Situs Web:}

Bilandoro, Antoius (ed), 2018, Lima Jalan Menuju Kekudusan Menurut Gaudate Et Exultate, dalam https://www.hidupkato lik.com/2018/04/12/20004/lima-jalan-menuju-kekudus an-me nurut-gau dete-et-exsultate/, diunduh pada tanggal 17 November 2019).

Kho, Budi, 2017, Pengertian Metode 5W1H dalam Manufakturing, dalam https://ilmumanajemenindustri.com/pengertian-metode-5w1h-dalammanufakturing/, diunduh pada tanggal 10 November 2019. 
Listiati, Ingrid, 2018, Semua Orang Dipanggil untuk Hidup Kudus, dalam http://www.katolisitas.org/bagaimana-caranya-untuk-hidup-kudus/, diunduh pada tanggal 22 November 2019 